Gadjah Mada International Journal of Business

September 2002, Vol. 4, No. 3, pp. 347-359

\title{
AN EMPIRICAL EXAMINATION OF THE DIVIDEND INFORMATION CONTENTS IN THE BALANCE SHEET: A Signaling Approach*
}

\author{
Agus Sartono \\ Anna Maria Sri Asih
}

\begin{abstract}
This study examines whether the changes in the financial statements and dividends can together provide a better information transmittal system to deliver missing private information on the firm using Indonesian firms as the sample. In doing so, this study consider three components in evaluating the dividend signaling theory: the expected content favorableness, the sign of dividend change, and the role of dividend signal. The finding shows that in Indonesia, the market reactions to the dividend announcements depend on the role of dividend signals, whether it is confirmatory, clarificatory, or unclear. The other finding shows that this market is more concern to the content expected favorableness rather than to the dividend sign.

Keywords: dividend; balance sheet; signaling; role; clarificatory; Indonesia
\end{abstract}

*) We thank Klaus Schredelseker, Frank Mueleck, Jurgen Huber, seminar participants at the University of Innsbruck, Austria and two anonymous referees. Any remaining errors are our responsibility. 


\section{Introduction}

The finance and economic literature about dividends usually assumes that managers are perfect agents of investors. Economists find dividend mysterious. The celebrated articles by Merton Miller and Franco Modigliani declared themirrelevant because investors could home-brew their own dividends by selling from or borrowing against their portfolios. Meanwhile the firms that issued the dividends would also incur costs to float new securities to maintain their optimal investment policies. Dividend is hard enough to be explained. In the stock market, a company should set its dividend policy, which involves the decision to pay out earnings versus retaining them for reinvestment in the firm. Basically, the firm's value is influenced by owner's equity and debt. In the stock price model that has constant growth, a higher dividend payment tends to increase the stock price. The increase in the stock price means the increase in the firm's value. However, the higher dividend payout ratio the lower the company's ability in investment as well as the company's growth, which finally may cause the stock price decreases because investors do react to the dividend change announcements. Therefore, in an attempt to maximizing the shareholder's wealth, it is important to consider the relationship between dividend and the firm's value.

Brigham (1999, p.47) note that dividend changes can provide signals about managers' beliefs as to their firms' future prospects. Dividend reductions generally have a significant effect on a firm's stock price. Since managers recognize this, they try to set dollar dividends low enough so that there is only a remote chance that dividend will have to be reduced in the future. Of course, unexpectedly large dividend increases can be used to provide positive signals.

Asymmetric information will lead to the market reaction. Managers in general have better information than outside investors. Elfakhani (1995) stated that the information is valuable if the investments in place or opportunities to invest can have positive effect in the firm's future cash flows, and in this circumstance, managers must use expensive, and credible, dividends to communicate this private information to the market.

The signaling system explained by Elfakhani (1995), involves three corporate attributes: capital investment, financing and agency decisions, all of which contribute to the firm's future cash flows. Moreover, he noted that most of studies about dividend signaling theory not focused on all of those three attributes. Furthermore, the events of preceding dividend changes also ignored. In fact, Aharony and Swary (1980) found that these events might reflect on the magnitude and direction of stock price response to dividend announcement.

The main process of signaling system used in this paper is that the three corporate attributes above are transmitted to the market in two phases. The first is through financial statement, which is the mandatory one. The second is through the discretion to announce a dividend change as signaling means. In the first phase, investors may evaluate the financial statement for its favorableness and its clarity of its three corporate attributes, whether it is clear or unclear. In the second phase, the dividend signals can confirm good, bad or flat news already observed in the phase one. Or, it can clarify the ambiguous part in the phase one; so that, the information becomes clearly good, clearly bad, still ambiguous, or remains flat. The other possibility is the information contained in the 
Sartono \& Sri Asih-An Empirical Examination of the Dividend Information Content in...

dividend announcement can be unclear, and therefore has less significant explanatory power.

The examination of signaling process in this paper employed the research method done by Elfakhani (1995), where the stock price response to dividend signal is jointly determined by three factors: the expected content favorableness from the dividend signal, the sign of dividend change, and the dividend signaling role.

In other words, this research mainly takes the same approach or a replication research of the Elfakani (1995) using the information from the Jakarta Stock Exchange. The main research purpose is to examine whether the same conclusion could be drawn and whether there is information contents on dividend of public firm in Indonesia. In short, the transmittal process and dividend signal will be examined to investigate the role of dividend change, and expected content of favorableness.

\section{Literature Review}

Much research about dividend announcement have been done, such as Char4est (1978); Lang and Litzenberger (1989); Penman (1983); Watts (1973); Pettit (1976); and Aharony (1980). Generally, the result showed that the dividend increases or dividend decrease can give significant effects on the share price.

The irrelevance of dividend policy to firm valuation observed by Miller and Modigliani (1961) continues to challenge both theorists and practitioners. In general, firms maintain target dividend payouts over time and investors receive cash dividends and do react to dividend change announcements. Therefore, for wealth maximisers, knowledge of how dividend relates to the value of the firm is a nontrivial issue (Elfakhani 1995). According to Kale and Noe (1990), many theories concerning the value of dividends expand on the role of dividend as a signal of firm quality. While these models elaborate on the original signaling idea in Miller and Modigliani (1961), they retain the notion that the dividends convey the information concerning the level of current or future economic profits.

The signaling hypothesis holds that firms use dividends to signal asymmetric information, which induces a reassessment of the firm's expected future earnings and a simultaneous adjustment of share price (Manakyan and Carroll 1990). Several studies, such as John and Williams (1985), Miller and Rock (1985) examine theoretically the mechanisms by which dividends can serve as signals.

Another outright empirical research, e.g. Aharony and Swary (1980), Dyle and Weigand (1998), Manakyan and Carroll (1990), focused on the link between the signal and the market's reassessment of the stock prices movement. In general, evidence is consistent with the use of dividends as signals in that the market reacts positively to dividend increases and negatively to dividends cuts.

Ross (1977) and Battacharya (1979) integrated the information content hypothesis with the signaling theory. They demonstrate that dividends provide information about the firm's future cash flow and thus the dividend decision can changes a firm's value. Their hypothesis assumes that managers possess private information about the firm's attributes not known to the market. This information is valuable if the investments in place or opportunities to invest can have positive effect on the firm's future cash flows. In this circumstance, managers must use expensive, and credible, dividends to communicate this private information to the market, (Elfakhani 1995). 
Gadjah Mada International Journal of Business, September 2002, Vol. 4, No. 3

In addition, he proposed that in a world of asymmetric information, three corporate attributes - capital investment, capital structure, and agency - is transmitted to the market in the financial statements and dividend announcement. The financial statement published by firms leading the investors to the revealed earnings figures. Therefore the performance of the firms can be evaluated from its financial statement, in the case that the earnings announcement leads the dividend announcement, before evaluating the information content in the dividend. Nonetheless, investors are more interested in the financial statements with the details leading to the revealed earnings figures, Swaminathan and Weintrop (1991). Using the information contained in the balance sheet, the investors can infer the meaning and direction of the firm's attributes. The dividend announcement carried out after the earnings announcement can confirm the market understanding of already released information, Elfakhani (1995). Moreover, the evidence in the research conducted by Manakyan and Caroll (1990) indicated that the combined influence of the lagged dividends on earnings is not significant, while the combined influence of lagged earnings in dividends is significant. Thus, in aggregate, direction of causality is from earnings to dividends.

Discussing the earnings and the dividend announcements, there are separate effects of earnings as part of balance sheet and dividend announcements on abnormal returns to equity, Easton(1991). Kane, Lee and Marcus (1984) argued that, in view of the noise associated with both earnings and dividend announcements, investors might be interested in the consistency of these signals. They found evidence of an interaction effect of earnings and dividend announcements on abnormal returns to equity.

\section{The Signaling Mechanism of Balance Sheet and Dividend Announcements}

The investments and financing decisions are made at the management's discretion. Knowing the investors' perception, managers use the release of earnings announcements to validate some of their verbal declarations (Kane et al. 1984). Nonetheless, investors are more interested in the financial statements with the details leading to the revealed earnings figures (Swaminathan and Weintrop 1991). Financial statements can be subject to manipulation. However, informed investors can still use it to estimate the value of the firm's attributes. Thus, the release of balance sheet constitutes the first phase of the information transmittal process.

As stated by Elfakhani (1995), in the first phase, outsiders use balance sheet changes to infer the meaning and direction of the firm's attributes. These changes can mean good, bad or flat news. As information content of balance sheet is quite clear with little uncertainty, in the second phase, the discretion in the dividend changes can only confirm market understanding to the information content of balance sheet already released. In short, dividend changes have no signals about future activities. In the other condition, if information content of balance sheet in the first phase does not improve certainty about the meaning and direction of released information, then in the second phase, dividend change signals can be valuable if it provides clear information about the firm's future success. If the dividend signal fails to clear uncertainty or is not efficient, then this signal is unclear. The conjecture is that a confirmatory signal is expected to cause little positive market response to good news and small negative response to bad news. 
Sartono \& Sri Asih-An Empirical Examination of the Dividend Information Content in...

Clarificatory signals bring strong positive (negative) market reaction to good (bad) news. Unclear signals usually do not eliminate all uncertainies surrounding conflicting news. Thus, they provoke lesser market movements than clarificatory signals. Thus, the three types of dividend signaling role rank from most to least valuable. A clarificatory signal has the highest value and a confirmatory signal has the lowest value.

The transmittal process will be examined in order to investigate the validity of the testing methodology in interpreting the dividend signal by its role, dividend change, and expected content of favorableness. The testable contention is that this process can contribute a better assessment of the dividend signal and the firm's value.

\section{Variable Description}

Variables used in evaluating the changes component of balance sheet and dividend are: cash (C), investment (I), common stocks (CS), retained earnings (RE), bond (B) and dividends (D). Those variables can be defined as follow:

a. $C$ is defined as all current assets except inventory.

b. I is set as all net fixed assets plus inventory.

c. $B$ includes short and long term liabilities.

d. CS combines common stocks and paidin-capital.

e. $D$ is defined as cash dividend.

Changes exceeding 5 percent for $C, I$, $B$, and $R E$ are classified as $>0$; these for $R E$ are as $<0$; otherwise they are included in the no change (-0) category. This filter is used to account for classification error and to capture only significant changes. Following Kalay and Lowenstein (1985), divi- dend omissions are recorded as regular decreases in dividends. Newly initiated dividends are treated as increases in dividends.

\section{Sample Selection}

The sample of this study consists of 240 public companies, which give cash dividend and have the same fiscal-years end (December). Financial institutions are discarded because they have different conditions and policies with manufacturing companies; the remaining sample is 202 companies. The firms reporting negative earnings for two years are dismissed, so the number of companies reduce to 199 companies. The companies in this sample also should release the financial statement before announcing the dividend. Therefore, the firms that announce dividend within 45 days after the financial statement release are admitted in the sample, otherwise they are dropped.

The number of companies announces dividend after the financial release is 194 companies. Those final sample fall into two group, 52 companies announce dividend within 45 days and 142 companies announce dividend more than 45 days after the financial statement released. To control the impact of other variables, companies having stock split, acquisition, or merger, stock dividend and bonus shares are excluded from the sampling frame. This research does not make separate analysis of each group and it will be done for another research.

\section{Analysis Method}

\section{Evaluating the Dividend Signal}

As stated before, investors evaluate the signaling mechanisms by considering 
three components. They are expected content favorableness from dividend signal (flat, good, bad, or ambiguous); the sign of dividend change (+ or -); and the role of dividend signal (confirmatory, clarifycatory or unclear). The sign of dividend change reflects size and strength of the expected market reaction. This in turn depends on the role of the signal.

The three role of dividend towards the information content brought in the balance sheet announcements before the dividend announcements are defined as follows:

a. Confirmatory: confirmatory signal occurs if a single attribute can project one value about the revealed attribute both before and after the dividend announcement. If the market interpretation of balance sheet changes reflecting the firm's attributes is simple and straightforward, a consensus firm value can then be reached. In this case, reassured investors react based on their appreciation of the revealed attribute.

b. Clarificatory: clarificatory signal occurs if balance sheet changes include more than one attribute and may carry conflicting news (simultaneous positive and negative news). In this case, the interpretation of balance sheet information is less clear, and the dividend announced can clarify one of the possibilities of conflicting news from balance sheet items.

c. Unclear: this signal does not carry any clear explanation even for conflicting news. The dividend announced also cannot make the information of changes in balance sheet items clearer. This unclear role does not mean that the dividend signal has a zero value; instead it is expected to have a net good or net bad effect on the stock price. This signal would not have the same value as a clarificatory signal.

So, in this classification, all sample will be divided into several group based on its expected favorableness, its dividend sign, and its signaling role. The objective of this classification is to test the hypotheses in each group as well as in group combinations.

\section{Table 1. The Exemplified Role of Dividend Signal}

\begin{tabular}{|c|c|c|c|c|c|}
\hline \multicolumn{2}{|c|}{$\begin{array}{c}\text { Phase one: Balance sheet } \\
\text { Announcement }\end{array}$} & \multicolumn{2}{|c|}{$\begin{array}{c}\text { Phase two: Dividend } \\
\text { Announcement }\end{array}$} & \multicolumn{2}{|c|}{ Signaling Evaluation } \\
\hline $\begin{array}{c}\text { News } \\
\text { Favorableness }\end{array}$ & $\begin{array}{l}\text { Attribute } \\
\text { Clarity }\end{array}$ & $\begin{array}{c}\text { Expected } \\
\text { Favorableness }\end{array}$ & $\begin{array}{l}\text { Attribute } \\
\text { Clarity }\end{array}$ & $\begin{array}{l}\text { Signaling } \\
\text { Role }\end{array}$ & $\begin{array}{l}\text { Expected Market } \\
\text { Response }\end{array}$ \\
\hline Flat & Clear & Flat & Clear & Confirmatory & No Reaction \\
\hline Potentially Good & Clear & Good & Clear & Confirmatory & Low/Med Positive \\
\hline Potentially Bad & Clear & $\mathrm{Bad}$ & Clear & Confirmatory & Low/Med Negative \\
\hline Ambiguous & Unclear & Good or Bad & Clear & Clarificatory & Med/Hi Pos./Negative \\
\hline Ambiguous & Unclear & Ambiguous & Unclear & Unclear & $\begin{array}{l}\text { Low/Med Net } \\
\text { Pos./Negative }\end{array}$ \\
\hline
\end{tabular}


Sartono \& Sri Asih-An Empirical Examination of the Dividend Information Content in...

\section{Event study Method}

a. To calculate the actual return of shares, the following equation is used:

$$
\mathrm{R}_{\mathrm{it}}=\ln \left(\mathrm{P}_{\mathrm{it}} / \mathrm{P}_{\mathrm{it}-1}\right)
$$

b. The share's abnormal return, the difference between observed return of security $i$ and the expected return, as well as the expected return within 60 days are calculated using the following equation:

$$
\begin{aligned}
& \mathrm{AR}_{\mathrm{it}}=\mathrm{R}_{\mathrm{it}}-\mathrm{E}\left(\mathrm{R}_{\mathrm{it}}\right) \\
& \mathrm{E}\left(\mathrm{R}_{\mathrm{it}}\right)=\mathrm{a}_{\mathrm{i}}-\mathrm{b}_{\mathrm{i}} \mathrm{R}_{\mathrm{mt}}-\mathrm{e}_{\mathrm{it}} \\
& \mathrm{R}_{\mathrm{mt}}=\ln \left(\mathrm{IHSG}_{\mathrm{t}} / \mathrm{IHSG}_{\mathrm{t}-1}\right)
\end{aligned}
$$

c. The daily abnormal return above are then averaged across the portfolio of firms or all securities which increase, decrease or do not change their dividend level as follows:

$$
\overline{\mathrm{AR}}_{\mathrm{t}}=\sum_{\mathrm{t}-4}^{\mathrm{t}-5}\left[\left(\sum_{\mathrm{i}=1}^{\mathrm{n}} \mathrm{AR}_{\mathrm{it}}\right) / \mathrm{n}\right]
$$

where $\overline{A R}_{t}$ is the mean abnormal return, which is calculated by forming an equally weighted of all individual abnormal returns for each event day (n).

To test for significance of the impact of the event during period, the abnormal return can be added to obtain the cumulative abnormal return (CAR) for the individual security over the period. The cumulative abnormal returns are calculated over the entire event period of the group by dividing this event period into three parts: pre-announcement ( $t-4$ to $t-1)$, announcement $(0$ to $t+1)$, and post announcement $(t+2$ to $t+5)$ using the following equation:

$$
\mathrm{CAR}=\sum_{\mathrm{k}}^{1} \mathrm{AR}_{\mathrm{k}}
$$

where $k$ and $l$ are the starting and last day of each part (for example, $\mathrm{k}=\mathrm{t}-4 \mathrm{ad} \mathrm{l}=\mathrm{t}-1$ for pre-announcement).

\section{Hypotheses}

The uncertainty about the firm's state can be resolved after the balance sheet announcement. Alternatively, this may have to wait the dividend announcement or alternative signals. The common knowledge in the recent dividend literature is that dividend announcement contains valuable information not known to the market (Bhattacharya 1979; Miller and Rock 1985; and Charest 1978). Therefore the first hypothesis explains the effect of dividend signaling role on stock prices toward balance sheet information, which is released before the dividend announcement. The first hypothesis is formulated as follows: $H_{1}$ : The dividend signal (confirmatory, clarificatory, or unclear) affects share price following the dividend announcement.

The dividend signaling models suggest that managers increase dividends only when they are confident that higher dividends can be maintained with higher subsequent cash flow. Evidence from previous research is consistent with the use of dividends as signals in that the market reacts positively to dividend increases and negatively to dividend cuts (John and William 1985, Watts 1973; and Lang and Litzenberger 1989). Thus, the second hypothesis is used to examine the relationship between sign of dividend change and stock price behavior. The second hypothesis is stated as follows:

$\mathrm{H}_{2}$ : Dividend change(increase, decrease, or flat) affects share price following the dividend announcement.

Since the confirmatory and unclear signals provoke lesser market movements 
than clarificatory signals to minimize problem arises, then the next hypotheses investigate the case of clarificatory signals combined with the sign and the content of favorableness of the dividend. This last hypothesis is inline with Swaminathan and Weintrop (1991); Elfakani (1995) and Asquisth and Mullins (1983). The third hypothesis is formulated as follows:

$H_{3}$ : Clarificatory signal conditioned on the sign of dividend change (increase, decrease or flat) and the content favorableness (good or bad) affects share price following the dividend announcement.

\section{Results}

The results of the test for Hypothesis1 is shown in Table 2. The table covers three parts of test period: pre-announcement period (-4 to -1), announcement period $(0,+1)$, and post announcement period $(+1$ to +5$)$.

The probability of the outcome is shown in parentheses under the cumulative abnormal return (CAR). Evaluating Table 2, it is revealed that among the three types of dividend signaling role, the clarificatory signal has the highest market response. From the significance level, the clarificatory signal is the only one that has significant number on the announcement date and post announcement date at the 0.031 and 0.032 levels, whereas totally it is significant at the 0.004 levels. The other two signals, confirmatory and unclear signal, have no significant result. It means that these two signals do not add to what the market already knows from other managerial decisions. The conclusion can be drawn from here is if the dividend signal can improve the clarity of the firm's condition, then the market reaction becomes stronger.

Table 3 shows the results of Hypothesis- 2 testing on the impact of dividend change on stock prices. From the significance number, all dividend changes are statistically significant on the post announcement and on the total test period. The dividends with positive sign bring positive market reactions. It is quite clear that most of the dividend increase bring good news to the market. To the next sign, the stable dividend, the market reactions show negative number of average abnormal returns. This can be explained that the stable dividend in this sample indicates more bad news than good news. This kind

Table 2. CAR Results for Dividend Signal Hypothesis-1

Hypothesis-1 examines the three roles of dividend signaling: confirmatory, clarificatory, and unclear. The numbers in parentheses are p-values. The sample period is 1998-2000.

\begin{tabular}{|c|c|c|c|c|}
\hline Signaling Role & $\begin{array}{l}\text { Pre-Announcement } \\
(-4 \text { to }-1)\end{array}$ & $\begin{array}{l}\text { Announcement } \\
\qquad(0 \text { to }+1)\end{array}$ & $\begin{array}{l}\text { Post-Announcement } \\
(+2 \text { to }+5) \\
\end{array}$ & $\begin{array}{c}\text { Total } \\
(-4 \text { to }+5)\end{array}$ \\
\hline Confirmatory & $\begin{array}{c}0.006932877 \\
(\mathbf{0 . 9 1 3 )}\end{array}$ & $\begin{array}{c}-0.016793889 \\
\quad(\mathbf{0 . 3 8 9})\end{array}$ & $\begin{array}{l}0.025693256 \\
(\mathbf{0 . 2 1 2})\end{array}$ & $\begin{array}{l}0.015832243 \\
\quad(\mathbf{0 . 7 5 4})\end{array}$ \\
\hline Clarificatory & $\begin{array}{l}0.025590618 \\
\quad(\mathbf{0 . 2 4 2})\end{array}$ & $\begin{array}{c}0.014975276 \\
\quad(\mathbf{0 . 0 3 1}) *\end{array}$ & $\begin{array}{c}0.08105197 \\
(\mathbf{0 . 0 3 2}) *\end{array}$ & $\begin{array}{c}0.121617864 \\
(\mathbf{0 . 0 0 4}) *\end{array}$ \\
\hline Unclear & $\begin{array}{c}0.005076588 \\
(\mathbf{0 . 9 3 6 )}\end{array}$ & $\begin{array}{c}-0.015788846 \\
(\mathbf{0 . 3 2 1})\end{array}$ & $\begin{array}{c}0.022306427 \\
\quad(\mathbf{0 . 1 1 2})\end{array}$ & $\begin{array}{c}0.011594168 \\
(\mathbf{0 . 9 7 6 )}\end{array}$ \\
\hline
\end{tabular}

* Significant at .05 levels 
Sartono \& Sri Asih-An Empirical Examination of the Dividend Information Content in...

Table 3. CAR results for Dividend Signal Hypothesis-2

Hypothesis-2 examines the effect of dividend change on stock returns. Dividend can increase (+), remain stable (0), or decrease (-). The numbers in parentheses are pvalues. The sample period is 1998-2000.

\begin{tabular}{|c|c|c|c|c|}
\hline $\begin{array}{l}\text { Dividend } \\
\text { Change }\end{array}$ & $\begin{array}{l}\text { Pre-Announcement } \\
\qquad(-4 \text { to }-1)\end{array}$ & $\begin{array}{l}\text { Announcement } \\
\quad(0 \text { to }+1)\end{array}$ & $\begin{array}{l}\text { Post-Announcement } \\
\qquad(+2 \text { to }+5)\end{array}$ & $\begin{array}{c}\text { Total } \\
(-4 \text { to }+5)\end{array}$ \\
\hline (+) & $\begin{array}{c}0.020668881 \\
\quad(\mathbf{0 . 1 6 9 )}\end{array}$ & $\begin{array}{c}-0.00376756 \\
(\mathbf{0 . 3 5 2})\end{array}$ & $\begin{array}{c}0.027581235 \\
\quad(\mathbf{0 . 0 1 3})^{*}\end{array}$ & $\begin{array}{c}0.044482556 \\
(\mathbf{0 . 0 2 1}) *\end{array}$ \\
\hline$(O)$ & $\begin{array}{c}-0.004577925 \\
(\mathbf{0 . 1 3 5})\end{array}$ & $\begin{array}{c}-0.001544969 \\
(\mathbf{0 . 4 2 9})\end{array}$ & $\begin{array}{c}-0.001868886 \\
(\mathbf{0 . 0 7 9}) * * *\end{array}$ & $\begin{array}{c}-0.007991781 \\
(\mathbf{0 . 0 1 2}) *\end{array}$ \\
\hline$(-)$ & $\begin{array}{l}0.013386566 \\
\quad(\mathbf{0 . 5 5 1})\end{array}$ & $\begin{array}{c}0.019928982 \\
\quad(\mathbf{0 . 6 1 4})\end{array}$ & $\begin{array}{c}0.15526672 \\
(\mathbf{0 . 0 7 8})^{* *}\end{array}$ & $\begin{array}{c}0.188582269 \\
(\mathbf{0 . 0 4 7}) *\end{array}$ \\
\hline
\end{tabular}

* significant at .05 level; ** significant at .10 level

of situation is also happened at the dividend decreases, which brought positive reaction. With the same analysis, it may give indication that dividend decrease in this sample reveals more good news rather than bad news. It is important to be noted here that in fact, the dividend decrease does not always bring negative reaction. This result will be clearer when evaluating the later hypothesis.

Table 4 reports that clarificatory signals can significantly induce all of the dividend change, whether it is increases, flat or decreases on the post announcement period and on the total test period (Hypothesis III, Panel A).

In Panel B, the dividend having good news has stock price adjustment after the announcement day, but clarificatory signal that bring both good and bad news induce significantly positive or negative overall stock price adjustments. Panel C reports that signals bringing good news is consistently show strong performance. Table 3 and 4 that show how the dividend decreases can bring positive market reactions, confirm this result. The clarificatory signals that have decreasing number of dividend and carrying good news is also significant at 0.032 and 0.021 levels. In hypotheses- 2 it is significant at the 0.078 and 0.047 levels.

This finding is also consistent with Elfakhani's (1995) as well as Swaminathan and Weintrop (1991), which also showed that dividend decreases could still import significant positive market reactions. It can be consistent only if there is other corporate good news revealed through the firm's performance on the balance sheet items. Most of the samples included in the portfolio of clarificatory signals with decrease dividend have an increasing number in investment.

The flat or stable dividend in fact can bring negative reactions. It is shown in Table 3 and Table 4 on Panel A that totally the stable dividend results in negative market reactions. In Panel C, it is separated between the stable clarificatory dividends that bring bad news and good news. Both news could bring negative market reactions although both of them show positive and negative number of average abnormal returns significantly (Panel C). It is because from the magnitude, the negative reaction is bigger than the positive one. 
Gadjah Mada International Journal of Business, September 2002, Vol. 4, No. 3

Table 4. CAR results for Dividend Signal Hypothesis: The Clarificatory Signal Case Hypothesis-3 examine the clarificatory signal conditioned on the sign of dividend change and the information favorableness, individually and jointly. The numbers in parentheses are p-values. The sample period is 1998-2000.

\begin{tabular}{|c|c|c|c|c|}
\hline Hypotheses-3 & $\begin{array}{l}\text { Pre-Announcement } \\
\qquad(-4 \text { to }-1)\end{array}$ & $\begin{array}{l}\text { Announcement } \\
\qquad(0 \text { to }+1) \\
(+2 \text { to }+5)\end{array}$ & $\begin{array}{c}\text { Post- } \\
\text { Announcement }\end{array}$ & $\begin{array}{c}\text { Total } \\
(-4 \text { to }+5)\end{array}$ \\
\hline \multicolumn{5}{|l|}{ PANEL A } \\
\hline Clarificatory, + & $\begin{array}{c}0.038940935 \\
(\mathbf{0 . 1 4 4 )}\end{array}$ & $\begin{array}{c}0.002175395 \\
\quad(\mathbf{0 . 6 3 6})\end{array}$ & $\begin{array}{c}0.042554878 \\
(\mathbf{0 . 0 9 1})^{* *}\end{array}$ & $\begin{array}{c}0.083671208 \\
(\mathbf{0 . 0 1 1})^{*}\end{array}$ \\
\hline Clarificatory, 0 & $\begin{array}{c}-0.004577925 \\
\mathbf{( 0 . 1 3 5 )}\end{array}$ & $\begin{array}{c}-0.001544969 \\
\mathbf{( 0 . 4 2 9 )}\end{array}$ & $\begin{array}{c}-0.001868886 \\
(\mathbf{0 . 0 7 9 )} * *\end{array}$ & $\begin{array}{c}-0.007991781 \\
(\mathbf{0 . 0 1 2})^{*}\end{array}$ \\
\hline Clarificatory,- & $\begin{array}{c}-0.00191183 \\
(\mathbf{0 . 8 0 2})\end{array}$ & $\begin{array}{c}0.052705024 \\
(\mathbf{0 . 2 9 9})\end{array}$ & $\begin{array}{l}0.20283705 \\
(\mathbf{0 . 0 3 2} *\end{array}$ & $\begin{array}{c}0.253630245 \\
(\mathbf{0 . 0 2 1}) *\end{array}$ \\
\hline \multicolumn{5}{|l|}{ PANEL B } \\
\hline Clarificatory, Good News & $\begin{array}{c}0.036901 \\
(\mathbf{0 . 1 3 2})\end{array}$ & $\begin{array}{c}0.024981 \\
(\mathbf{0 . 1 9 0 )}\end{array}$ & $\begin{array}{c}0.106593 \\
(\mathbf{0 . 0 2 5})^{*}\end{array}$ & $\begin{array}{l}0.168475 \\
(\mathbf{0 . 0 0 2}) *\end{array}$ \\
\hline Clarificatory, Bad News & $\begin{array}{l}-0.03322 \\
(\mathbf{0 . 5 7 9 )}\end{array}$ & $\begin{array}{l}-0.03705 \\
(\mathbf{0 . 5 2 2 )}\end{array}$ & $\begin{array}{l}-0.05176 \\
(\mathbf{0 . 2 7 3 )}\end{array}$ & $\begin{array}{c}-0.12204 \\
(\mathbf{0 . 0 9 3}) * *\end{array}$ \\
\hline \multicolumn{5}{|l|}{ PANEL C } \\
\hline Clarificatory, + , Good News & $\begin{array}{l}0.057028 \\
(\mathbf{0 . 0 5 6 ) * *}\end{array}$ & $\begin{array}{l}0.013226 \\
(\mathbf{0 . 0 1 9 )} *\end{array}$ & $\begin{array}{l}0.067252 \\
(\mathbf{0 . 0 8 3}) * *\end{array}$ & $\begin{array}{l}0.137506 \\
(\mathbf{0 . 0 0 1})^{*}\end{array}$ \\
\hline Clarificatory, + , Bad News & $\begin{array}{c}-0.03793 \\
(\mathbf{0 . 6 1 6 )}\end{array}$ & $\begin{array}{c}-0.04479 \\
(\mathbf{0 . 5 3 7 )}\end{array}$ & $\begin{array}{c}-0.06241 \\
(\mathbf{0 . 2 8 5})\end{array}$ & $\begin{array}{c}-0.14513 \\
(\mathbf{0 . 1 0 8})\end{array}$ \\
\hline Clarificatory,0, Good News & $\begin{array}{c}0.005256 \\
(\mathbf{0 . 0 1 1 )} *\end{array}$ & $\begin{array}{l}0.003018 \\
(\mathbf{0 . 0 0 9 ) * * *}\end{array}$ & $\begin{array}{l}0.005433 \\
(\mathbf{0 . 0 0 6}) * *\end{array}$ & $\begin{array}{l}0.013707 \\
(\mathbf{0 . 0 0 0})^{*}\end{array}$ \\
\hline Clarificatory,0, Bad News & $\begin{array}{l}-0.01441 \\
(\mathbf{0 . 0 3 3})^{*}\end{array}$ & $\begin{array}{c}-0.00611 \\
(\mathbf{0 . 2 4 1 )}\end{array}$ & $\begin{array}{l}-0.00917 \\
(\mathbf{0 . 0 0 6})^{* * *}\end{array}$ & $\begin{array}{l}-0.02969 \\
(\mathbf{0 . 0 0 0 )} *\end{array}$ \\
\hline Clarificatory,-, Good News & $\begin{array}{c}-0.00191183 \\
(\mathbf{0 . 8 0 2})\end{array}$ & $\begin{array}{c}0.052705024 \\
(\mathbf{0 . 2 9 9})\end{array}$ & $\begin{array}{l}0.20283705 \\
\quad(\mathbf{0 . 0 3 2}) *\end{array}$ & $\begin{array}{c}0.253630245 \\
(\mathbf{0 . 0 2 5})^{*}\end{array}$ \\
\hline \multirow[t]{2}{*}{ Clarificatory,-, Bad News } & $\sim$ & $\sim$ & $\sim$ & $\sim$ \\
\hline & $\sim$ & $\sim$ & $\sim$ & $\sim$ \\
\hline
\end{tabular}

* Significant at .05 level; ** Significant at .10 level. Panel B and C indicate that clarificatory signals are conditioned on the signed of dividend change and the information favorableness. 
Sartono \& Sri Asih-An Empirical Examination of the Dividend Information Content in...

This finding indicates that stable dividend Does not always bring positive reaction. It is still influenced by firm's performance showed in the balance sheet. When the news from the financial statement gives a bad indicator then it is possible that the market will react negatively although the dividend remain stable. It reveals that the financial statement released by firm could give significant contribution to the market reaction toward dividend announcement.

\section{Conclusion}

Integrating the information content in the balance sheet and dividend give significant signaling effect in the market reaction. This paper reveals that the classification of dividend signal into three components could improve the understanding of the firm's value. The result from this paper shows that when the level of certainty towards the firm's performance before the dividend announcement, which can be reached through firm's information sources such as balance sheet, is high, then the clarifying role become minimal. In this circumstance, information contents in dividend become less efficient and has little value to the market. On the contrary, when the market knows are less, then the more efficient the dividend's clarifying role in the market reaction. In this condition, the market becomes eager to receive the clarificatory signal and to assess its contents as carrying good or bad news. This finding is consistent with those of previous research.

Thus, clarificatory signals bring strong positive or negative market reaction to good or bad news rather than the confirmatory and unclear signals, which provoke lesser market movements. The finding also shows that in Indonesian case, dividend signals that send good news cause larger price movements rather than bad news. It means the bad news carried by the dividend may bring little information. Another finding shows that the market reactions depend more on the expected content favorableness than on the sign of dividend change. This fact is showed that not all dividend decreases bring bad news. It could be due to the sampling problem as well as market condition. The minor inconsistency with the theory provide potential research topic in the future.

\section{References}

Aharony, J., and I. Swary. 1980. Quarterly dividend and earnings announcements and stockholder's return: An empirical analysis. Journal of Finance 35: 1-12.

Anthony, J., Hawkins, and Merchant. 1999. Accounting: Text and Cases (10 ${ }^{\text {th }}$ Eds.). McGrawHill.

Ambarish, R., K. John, and J. William. 1987. Efficient signaling with dividends and investments. Journal of Finance 42: 321-343.

Asquith P, and D. Mullins. 1983. The impact of initiating dividend payments on the shareholders' wealth. Journal of Business 56: 27-44.

Bhattacharya, S. 1979. Imperfect information, dividend policy and the bird in the hand fallacy. Bell Journal of Economics 10: 259-270. 
Brigham, E. F., and L. C. Gapenski. 1999. Financial Management Theory and Practice ( $6^{\text {th }}$ Eds.). New York: The Dryden Press International Edition.

Brown, S. J., and J. B. Warner. 1985. Using daily stock return: The case of event studies. Journal of Financial Economics 4: 3-31.

Charest, G. 1978. Dividend information, stock returns and market efficiency. Journal of Financial Economics 6: 297-330.

Dyle, A., and R. Weigand. 1998. The information content of dividend initiation: Additional evidence Financial Management 27: 27-35.

Easton, S. 1991. Earnings and dividends: Is there an interaction effect? Journal of Business Finance \& Accounting 18: 255-266.

Elfakhani, S. 1995. An empirical examination of the information content of balance sheet and dividend announcements: A signaling approach. Journal of Financial And Strategic Decisions 8 (2): 65-76.

Foster, G. 1986. Financial Statement Analysis ( $2^{\text {nd }}$ Eds.). New Jersey: Prentice-Hall International Inc.

Hardi, M. 1999. Reaksi pasar modal Indonesia terhadap pengumuman dividen (Periode 1996-1997). Internship Report. Indonesia: Master of Management Program, Gadjah Mada University.

Healey, P. M., and K. G. Palepu. 1988. Market rationality and dividend announcement effect. Journal of Financial Economics 12: 149-176.

John, K., and J. William. 1985. Dividend, dilution, and taxes: A signaling equilibrium. Journal of Finance 40: 1053-1070.

Jones, C. P. 2000. Investment Analysis and Management ( $7^{\text {th }}$ Eds.). North Carolina: John Wiley and Sons Inc.

Kalay, A., and U. Lowenstein. 1985. Predictable wants and excess return: The case of dividend announcements. Journal of Financial Economics 14: 423-449.

Kale, J. R., and T. H. Noe. 1990. Dividend, uncertainty, and underwriting costs under asymmetric information. The Journal of Financial Research XIII (4) (Winter): $265-$ 277.

Kane, A., Y. Lee, and A. Marcus. 1984. Earning and dividend announcement: Is there a corroboration effect? Journal of Finance 39: 1091-1099.

Koch P. D., and C. Shenoy. 1999. The information content of dividend and capital structure policies. Financial Management 28 (4).

Kritzman, M. P. 1994. What practitioners need to know about event studies. Financial Analysts Journal (November-December): 17-20.

Lang, L. P., and R.H. Litzenberger. 1989. Dividend announcement: Cash flow signaling versus free cash flow hypothesis. Journal of Financial Economics 24: 181-192. 
Sartono \& Sri Asih-An Empirical Examination of the Dividend Information Content in...

Manakyan, H., and C. Carrol. 1990. An empirical examination of the existence of a signaling value function for dividends. The Journal of Financial Research 13: 201210 .

Miller, M., and F. Modigliani. 1961. Dividend policy, growth and valuation of shares. Journal of Business 34: 411-433.

Miller, M., and K. Rock. 1985. Dividend policy under asymmetric information. Journal of Finance 40: 1031-1052.

Niniek, D. P. 1998. Pengaruh pengumuman pembagian dividend tunai terhadap aktivitas volume perdagangan saham di BEJ. Internship Report. Indonesia: Master of Management Program, Gadjah Mada University.

Olson, G. T., and P. D. McCann. 1994. The linkages between dividends and earnings. The Financial Review 29: 1-22.

Penman, S. H. 1983. The predictive content of earnings forecasts and dividends. Journal of Finance 38: 1181-1199.

Pettit, R. 1976. The impact of dividend and earnings announcements, a reconciliation. Journal of Business 49: 86-96.

Ross, S. 1977. The determination of financial structure: The incentive Signaling approach. Bell Journal of economics 8: 23-40.

Swaminathan, S., and J. Wientrop. 1991. The information content of earnings, revenues, and expenses. Journal of Accounting Research 29: 418-427.

Wansley, J. W., C. F. Sirmans, J. D. Shilling, and Y. J. Lee. 1991. Dividend change announcement effects and earnings volatility and timing. Journal of Financial Research 14: 37-50.

Watt, R. 1973. The information content of dividends. Journal of Business 46: 191-211.

William, J. 1988. Efficient signaling with dividends, investment, and stock repurchases. The Journal of Finance XLIII (3) (July): 737-747. 